\title{
Acoustic characteristics of voice in different cycles of life: an integrative literature review
}

\author{
Evelyn Alves Spazzapan' \\ https://orcid.org/0000-0002-4191-359X \\ Viviane Cristina de Castro Marino ${ }^{1}$ \\ https://orcid.org/0000-0003-3495-9394 \\ Vanessa Moraes Cardoso 1 \\ https://orcid.org/0000-0002-4373-7884 \\ Larissa Cristina Berti ${ }^{1}$ \\ https://orcid.org/0000-0002-4144-2804 \\ Eliana Maria Gradim Fabbron' \\ https://orcid.org/0000-0001-5197-0347
}

Universidade Estadual Paulista, UNESP Marilia, São, Paulo, Brasil.

Project carried out at the Departamento de Fonoaudiologia, Faculdade de Filosofia e Ciências, Universidade Estadual Paulista Júlio de Mesquita filho - UNESP - Marília, São Paulo, Brazil.

Research support source: Coordenação de Aperfeiçoamento de Pessoal de Ensino Superior - CAPES.

Conflict of interests: Nonexistent

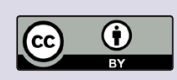

Received on: October 1st, 2018

Accepted on: September 23, 2019

Corresponding address:

Evelyn Alves Spazzapan

Rua Goiás, 808

CEP: 16900-049 - Andradina, São Paulo, Brasil

E-mail: evelyn_spazzapan@yahoo.com

\section{ABSTRACT}

Purpose: to carry out an integrative literature review about the acoustic characteristics of healthy voice production, from childhood to old age.

Methods: a bibliographic survey was conducted on the databases PubMed, SciELO, MEDLINE and LILACS, covering the last 10 years. Nineteen studies were found, meeting the proposed criteria, on acoustic measurements: $F_{0}$ (fundamental frequency), jitter, shimmer and/or noise measurements, in males and females, with normal voices in their different stages of life.

Results: the analysis showed that $\mathrm{F}_{0}$ is the most changing acoustic parameter as people grow up and grow old. Its values present gradual fall from childhood to old age in the female population, whereas among men such decrease lasts until adulthood. Jitter, shimmer and noise remain stable throughout childhood and adulthood, while shimmer and noise measurements increase in old age. In the literature, there is no consensus regarding increase of jitter measurements in the elderly.

Conclusion: from childhood to old age, in both genders, vocal changes take place which are reflected, especially by $F_{0}$. There is a scarcity of information on acoustics related to specific populations with ample age range, using the same methodology. The information in this study may guide future investigations aiming to understand natural changes occurring in the human voice, in addition to guiding in the clinical practice.

Keywords: Voice; Acoustic; Child; Adolescent; Adult; Elderly 


\section{INTRODUCTION}

From childhood to old age, the human voice goes through changes that may be identified through acoustic analysis ${ }^{1-3}$, an objective evaluation processing the vocal signal produced in the vocal folds and estimating vibration patterns, vocal tract shape and modifications in it ${ }^{4}$. Among the objective voice evaluations, the acoustic analysis is one of the most used tools for clinical and research purposes ${ }^{2,5}$, being favored by technological advances involving computers and programs specific for voice analysis ${ }^{6,7}$; this has brought about the emergence of trustworthy, quickly-obtained measurements ${ }^{4}$.

The acoustic analysis infers indirectly the vibration patterns of the vocal folds, as well as the vocal tract shape $^{4}$ in men and women of different age groups. This analysis offers quantitative information which enables deductions to be made on the laryngeal function, besides being a non-invasive instrument, making it easier to be used in research and in clinical practice. Particularly, such analysis aids in diagnosis ${ }^{5}$ and treatment monitoring ${ }^{5,8}$. Furthermore, it provides knowledge on vocal changes that naturally take place from childhood to old age in healthy people ${ }^{1-3}$.

Acoustic measurements reference values are extensively recommended for the comparison of findings obtained in clinical voice evaluation ${ }^{2,9,10}$. Hence, vocal changes that occur in the different cycles of life, in both genders, must be taken into account when searching for reference values for clinical comparisons. Some acoustic analysis software provides normality data for each investigated measurement ${ }^{11}$. However, the data composing these databases derive from speakers of different languages and, commonly, from a specific age group.

Scholars recommend comparison of normative data to be made with population of the same age group and speaking the same language ${ }^{12}$. In this sense, clinical populations must be compared to normality data obtained from subjects with similar characteristics. Besides being used as reference in comparison with clinical populations and in monitoring vocal therapy, the standardization of acoustic measurements may aid in understanding vocal changes taken place in people's speech throughout life.

Among the various existing acoustic parameters that characterize voice in the different cycles of life, there are some which stand out, namely: fundamental frequency $\left(F_{0}\right)$, short-term perturbation measurements of frequency and amplitude (jitter and shimmer), and noise measurements. These measurements are possible to be analyzed with different software ${ }^{7}$, and are frequently used to describe vocal characteristics in different age groups in normal5,13,14 and/or pathological ${ }^{12,15}$ conditions.

In general, descriptions of voice acoustic characteristics in normal conditions are presented in the literature for specific age groups. Particularly, information on $F_{0}$ and noise measurements for normal voices throughout human life ${ }^{1-3}$ are scarce, and the results obtained generally suggest that these measurements are important to reflect changes in vocal production, from childhood to old age, in both genders. Thus, it is understood that the knowledge on $F_{0}$ and noise measurements established in the literature up until now, both for specific age groups and for life span, may favor the clinical practice of voice therapists.

Perturbation measurements of frequency and amplitude may infer physiological aspects of the laryngeal system and of the vocal production, so possible variations in the jitter and shimmer measurements that may take place throughout life ${ }^{3}$ must be made known to the voice therapist. More specifically, knowledge on normal voice reference values established for specific populations enables comparisons to be made with pathological voices, in which acoustic signal irregularities are expected ${ }^{16}$.

Considering that $F_{0}$, jitter, shimmer and noise reference measurement values described for different age groups (child, adolescent, adult and elderly) may favor the clinical practice of voice therapists, such knowledge must be made available to researchers and workers in voice clinics. Thus, an updated survey of articles present in the literature is necessary, in order to systematize previous information on acoustic measurements in different age groups. Therefore, this study aimed at conducting an integrative review concerning acoustic characteristics of healthy voice production, from childhood to old age.

\section{METHODS}

This integrative literature review started with the theme of interest being identified and the following research question being defined, in order to guide the review: "What are the acoustic characteristics of vocal production of healthy individuals in the different cycles of life?". The articles were selected based on a survey conducted in the national and international scientific literature in specialized journals available on the databases: PubMed, SciELO, MEDLINE and 
LILACS. The descriptors and terms used to find the articles were defined after a query on DeCS (Health Sciences Descriptors) in both Portuguese and English, namely: voice (voz), acoustic (acústica), child (criança), adolescent (adolescente), adult (adulto), aged (idoso), aging (envelhecimento), and reference values (valores de referência). The search for the descriptors and their associations was made independently by two researchers, in the period between May and June 2018. The combinations used between the descriptors were: voice AND acoustic AND (child OR adolescent OR adult OR aged); voice AND acoustic AND reference values; Voice AND acoustic AND aging. Besides these, the combination life span AND voice was also included, due to the theme of interest of this investigation, and to studies that use life span as a descriptor, although it is not contemplated in DeCS.

As inclusion criteria, it was established that they would be original articles present on the selected databases from the last 10 years (from 2009 to 2018), available in full, in either Portuguese or English, possible to be accessed through the institution of origin. The articles needed to have investigated the characteristics of healthy voices of individuals in different cycles of life, through acoustic analysis, especially the $F_{0}$, jitter, shimmer and noise measurements. In these studies, healthy voices were considered to be those with the absence of established dysphonia in previous vocal evaluation.

The exclusion criteria were defined as the studies not directly related to the theme, studies involving subjects with dysphonia or with history of neurologic, metabolic, hormonal or head and neck diseases, or craniofacial anomalies, and studies investigating the effect of vocal techniques. Furthermore, studies investigating acoustic measurements by means of sequential speech (instead of sustained vowel) and those with level of scientific evidence of four and five (case studies and experience reports), according to the scale from the Oxford Centre for Evidence-Based Medicine ${ }^{17}$.

Initially, two researchers conducted an exploratory reading, through the titles and abstracts, in order to identify the studies that met the inclusion criteria. A total of 19 articles were selected to be read in full. The researchers did not agree about the inclusion of two articles, which were thus excluded from this research after discussion and consensus. The selection of studies is represented in Figure 1.

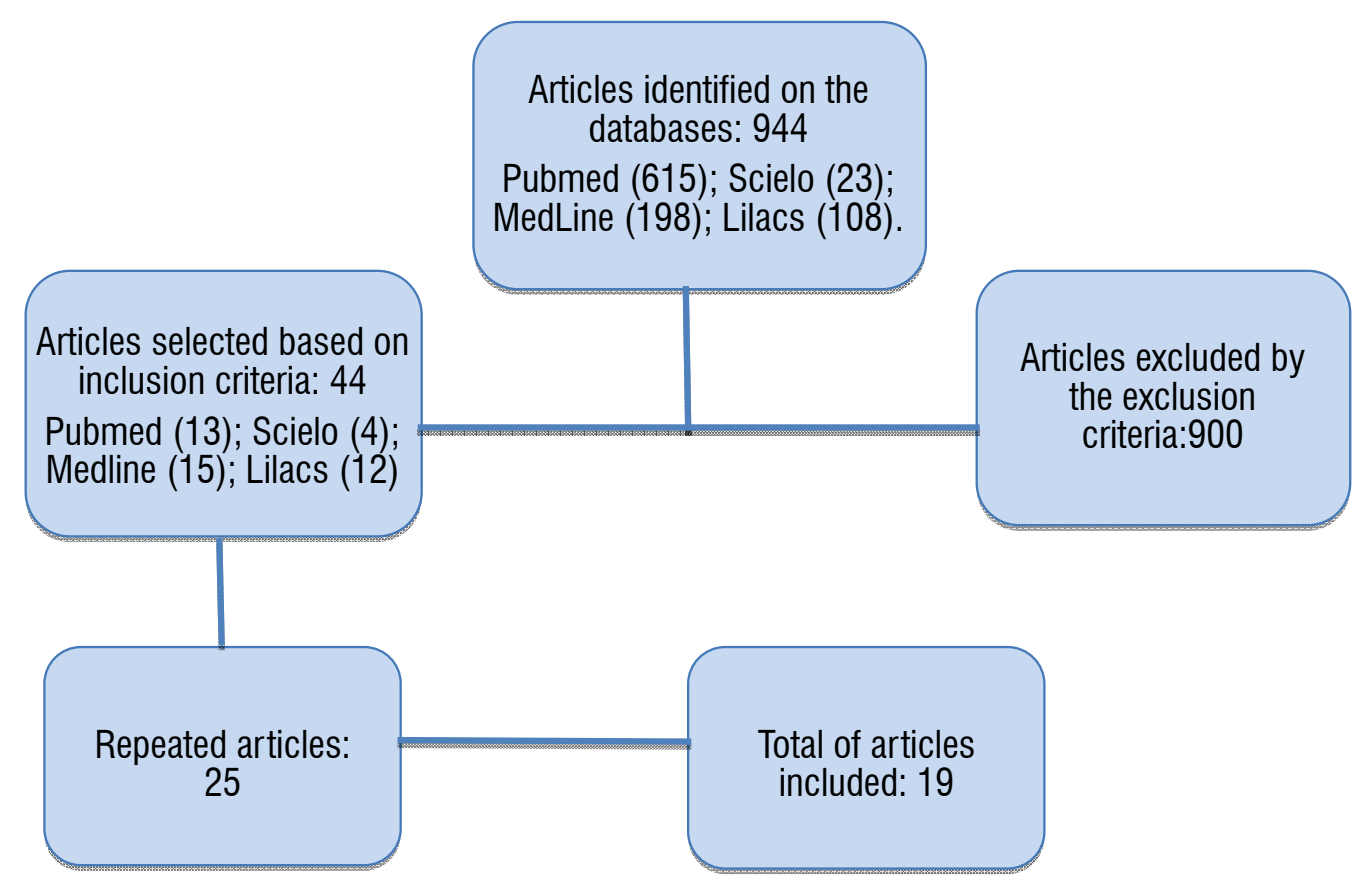

Figure 1. Selection and identification of the studies 
The studies were grouped together according to the acoustic measurements explored: $F_{0}$, jitter, shimmer, and noise measurements. This organization was proposed because they are the most commonly investigated ones for the description of vocal behavior in normal5, $12,13,14$ and pathological ${ }^{13,15}$ conditions, besides being possible to be analyzed through distinct acoustic analysis software ${ }^{7}$. Hence, such organization was chosen in order to favor the verification of acoustic changes in voice production occurred throughout life.

\section{LITERATURE REVIEW}

Based on the survey conducted on the databases PubMed, SciELO, MEDLINE and LILACS, 19 articles that met the inclusion criteria for this study were analyzed. These articles report acoustic characteristics of the voices of healthy individuals from different age groups.

This review presents information regarding the acoustic analysis of voice, separated in four acoustic parameters $\left(F_{0}\right.$, jitter, shimmer, and noise measurements) from childhood to old age.

In the following, the normality values are described for the measurement of $F_{0}$ (Figure 2), jitter (Figure 3), shimmer (Figure 4) and noise measurement (Figure 5), reported in the literature $\backslash$ for the different age groups, besides the information about population, acoustic analysis software, vowel used in each study, and $p$-value when there was statistically significant difference. On each figure, the studies are ordered according to the age of the subjects investigated, in order to facilitate the comprehension of acoustic changes taking place in each measurement, in the different cycles of life.

\section{Fundamental Frequency}

The $F_{0}$ is an acoustic measurement frequently used in research and in clinics. It is correlated with pitch and reflects the vibration speed of the vocal folds. Moreover, it is related to the biomechanical characteristics of the vocal folds, such as the strain of elastic fibers and the fibers of the vocal ligament $^{2}$. Such measurement is related to the anatomophysiologic characteristics of the vocal folds, as length, mass, vibration, tension and stiffness during phonation; for this reason, it is affected by the speaker's age and gender ${ }^{9,12}$.

The analysis of $F_{0}$ is of great relevance for studies aiming to understand voice in the different stages of life ${ }^{1-3}$, as it furnishes information enabling a better comprehension regarding laryngeal physiology, from childhood to old age.

\begin{tabular}{|c|c|c|c|c|c|c|c|}
\hline Author & $\begin{array}{l}\text { Nationality of the } \\
\text { population }\end{array}$ & Program used & $\begin{array}{l}\text { Stimulus } \\
\text { used }\end{array}$ & $\begin{array}{l}\text { Characteristics of } \\
\text { the population }\end{array}$ & Groups studied & $\mathrm{F}_{0}(\mathrm{~Hz})$ & $p$-value \\
\hline \multirow{8}{*}{$\begin{array}{c}\text { Tavares, Lábio and } \\
\text { Martins, }{ }^{18}\end{array}$} & \multirow{8}{*}{ Brazilian } & \multirow{8}{*}{ MDVP } & \multirow{8}{*}{ /a/ } & \multirow{8}{*}{$\begin{array}{c}N=240 \\
4 \text { to } 12 \text { years }\end{array}$} & \multirow{2}{*}{4 to 5 years } & M: 275.09 & \multirow{8}{*}{$\begin{array}{c}\mathrm{p}=0.001 \\
\text { (older }< \\
\text { younger) }\end{array}$} \\
\hline & & & & & & F: 257.14 & \\
\hline & & & & & \multirow{2}{*}{6 to 7 years } & M: 243.37 & \\
\hline & & & & & & F: 257.14 & \\
\hline & & & & & \multirow{2}{*}{8 to 9 years } & M: 227.30 & \\
\hline & & & & & & F: 258.93 & \\
\hline & & & & & \multirow{2}{*}{10 to 11 years } & M: 222.4 & \\
\hline & & & & & & F: 234.09 & \\
\hline $\begin{array}{l}\text { Finger, Cielo and } \\
\text { Schwarz }{ }^{20}\end{array}$ & Brazilian & PRAAT & /a/ & $\begin{array}{l}\mathrm{N}=56 \text { women } \\
18 \text { to } 38 \text { years }\end{array}$ & 18 to 38 years & F: 210.92 & NS \\
\hline Beber and Cielo ${ }^{28}$ & Brazilian & MDVPA & $/ \mathrm{a} /$ & $\begin{array}{l}\mathrm{N}=25 \text { men } \\
20 \text { to } 40 \text { years }\end{array}$ & 20 to 40 years & M: 120.16 & NS \\
\hline \multirow{6}{*}{$\begin{array}{c}\text { Dehqan, Ansari, } \\
\text { Bakhtiar'12 }\end{array}$} & \multirow{6}{*}{ Iranian } & \multirow{6}{*}{ Dr. Speech } & \multirow{6}{*}{ /a/ } & \multirow{6}{*}{$\begin{array}{c}N=90 \\
20 \text { to } 50 \text { years }\end{array}$} & \multirow{2}{*}{20 to 30 years } & $\mathrm{M}: 113.1$ & \multirow{6}{*}{$\begin{array}{c}p=0.000 \\
(F>M)\end{array}$} \\
\hline & & & & & & F: 214.5 & \\
\hline & & & & & \multirow{2}{*}{30 to 40 years } & M: 112.8 & \\
\hline & & & & & & F: 214.4 & \\
\hline & & & & & \multirow{2}{*}{40 to 50 years } & M: 112.5 & \\
\hline & & & & & & $\mathrm{F}: 215.0$ & \\
\hline
\end{tabular}




\begin{tabular}{|c|c|c|c|c|c|c|c|}
\hline Author & $\begin{array}{c}\text { Nationality of the } \\
\text { population }\end{array}$ & Program used & $\begin{array}{c}\text { Stimulus } \\
\text { used }\end{array}$ & $\begin{array}{c}\text { Characteristics of } \\
\text { the population }\end{array}$ & Groups studied & $\mathrm{F}_{0}(\mathrm{~Hz})$ & $p$-value \\
\hline \multirow[b]{2}{*}{ D'Haeseleer et al. ${ }^{21}$} & \multirow[b]{2}{*}{ Belgian } & \multirow[b]{2}{*}{ MDVP } & \multirow[b]{2}{*}{$/ \mathrm{a} /$} & \multirow{2}{*}{$\begin{array}{c}N=44 \\
20 \text { to } 28 ; 46 \text { to } 52 \\
\text { years }\end{array}$} & Youth & F: 202 & \multirow{2}{*}{$\begin{array}{c}p=0.007 \\
\text { (premenopause } \\
<\text { youth) }\end{array}$} \\
\hline & & & & & Premenopause & $\mathrm{F}: 190$ & \\
\hline \multirow{2}{*}{ Demirhan et al. ${ }^{5}$} & \multirow{2}{*}{ Turkish } & \multirow{2}{*}{ CSL } & \multirow{2}{*}{$/ \wedge /, / \mathrm{i} /, / \mathrm{u} /$} & \multirow{2}{*}{$\begin{array}{c}N=83 \\
18 \text { to } 32 \text { years }\end{array}$} & \multirow{2}{*}{18 to 32 years } & M: 127.11 & \multirow{2}{*}{$\begin{array}{c}p=0.000 \\
(F>M)\end{array}$} \\
\hline & & & & & & F: 239.78 & \\
\hline \multirow{3}{*}{ Tatar et al. ${ }^{22}$} & \multirow{3}{*}{ Turkish } & \multirow{3}{*}{ MDVP } & \multirow{3}{*}{ /a/ } & \multirow{3}{*}{$\begin{array}{l}N=89 \text { women } \\
20 \text { to } 42 \text { years }\end{array}$} & $\begin{array}{c}\text { Stage: } \\
\text { menstruation(l) } \\
\end{array}$ & $\mathrm{F}: 226.4$ & \multirow{3}{*}{$\begin{array}{c}p=0.01 \\
(I I I<I) \\
p=0.03 \\
(I I I<I I)\end{array}$} \\
\hline & & & & & $\begin{array}{c}\text { Stage: } \\
\text { postmenstruation } \\
\text { (II) }\end{array}$ & F: 223.9 & \\
\hline & & & & & $\begin{array}{l}\text { Stage: } \\
\text { premenstruation } \\
\text { (III) } \\
\end{array}$ & F: 213.4 & \\
\hline \multirow{6}{*}{$\begin{array}{l}\text { Zraick; Smith- } \\
\text { Olinde; Shotts }{ }^{19}\end{array}$} & \multirow{6}{*}{ American } & \multirow{6}{*}{$\begin{array}{l}\text { KayPENTAX } \\
\text { PAS Model }\end{array}$} & \multirow{6}{*}{$/ \mathrm{a} /$} & \multirow{6}{*}{$\begin{array}{c}N=157 \\
18 \text { to } 86 \text { years }\end{array}$} & \multirow{2}{*}{18 to 39 years } & M: 122.32 & \multirow{6}{*}{$\begin{array}{c}p=0.001 \\
(F>M) \\
p=0.001 \\
\text { (adults > } \\
\text { elderly) }\end{array}$} \\
\hline & & & & & & F: 214.74 & \\
\hline & & & & & 40 to 59 vears & M: 124.44 & \\
\hline & & & & & 40 to 59 years & F: 203.30 & \\
\hline & & & & & & M: 159.81 & \\
\hline & & & & & 60 to 86 years & F: 191.90 & \\
\hline & & & & $N=41$ & Youth & M: 113 & $p=0.001$ \\
\hline & & & & 70 to 90 years & routII & $\mathrm{F}: 210$ & (elderly M > \\
\hline Dehqan et al. ${ }^{9}$ & Iranian & Dr. Speech & $/ \mathrm{a} /$ & $\mathrm{N}=40$ & & M: 146 & young M) \\
\hline & & & & 20 to 49 years & Elderly & F: 194 & $\begin{array}{c}\text { (elderly } F< \\
\text { young } F \text { ) }\end{array}$ \\
\hline & & & & $N=159$ & Youth & M: 128 & \\
\hline Gov et al 8 & Canadian & Sonneta & $/ a /$ & 18 to 28 years; & 70uाiा & F: 251 & F- (elderly - \\
\hline & Lanadian & & a/ & $N=133$ & Flderly & M: 127 & $\begin{aligned} & \mathrm{F}= \text { (elderly }< \\
& \text { youth) }\end{aligned}$ \\
\hline & & & & 63 to 86 years & Elaenty & $\mathrm{F}: 211$ & \\
\hline & & & & & 60 to 69 years & F: 193.81 & \\
\hline Cerceau, Alves, & Brazilian & MDVP & /a/ & IV= $=0$ wolliell & 70 to 79 years & F: 195.71 & NS \\
\hline & & & & & Over 80 years & F: 187.60 & \\
\hline & & & & & 60 to 70 years & F: 182.16 & $p=0.02$ \\
\hline Fonsecan & Brazilian & PRAAT & lé/ & IN -20 & 71 to 80 years & F: 168.86 & (older < \\
\hline & & & & & +80 years & F: 148.69 & younger) \\
\hline & & & & $\mathrm{N}=60$ women & Youth & F: 215.47 & \\
\hline Menezes et al. ${ }^{25}$ & Brazilian & PRAAT & /a/ & $\begin{array}{l}20 \text { to } 35 \text { years } \\
60 \text { to } 82 \text { years }\end{array}$ & Elderly & $F: 227.20$ & NS \\
\hline Lortie et al. ${ }^{29}$ & Canadian & PRAAT & /a/ & $\begin{array}{c}N=81 \\
20 \text { to } 75 \text { years }\end{array}$ & * & * & $\begin{array}{c}\mathrm{p}=0.001 \\
\text { (elderly }< \\
\text { young and } \\
\text { middle-aged } \\
\text { adults) }\end{array}$ \\
\hline & & & & & Youth & M: 141.64 & \\
\hline Mezzedimi et al 26 & Italian & PRAAT & $/ a /$ & $N=142$ & Youth & F: 217.54 & $\begin{array}{c}p=0.001 \\
\end{array}$ \\
\hline & & PRAAI & d d & 20 to 93 years & Flderly & M: 139.56 & $\begin{array}{c}=\text { (youtul } \\
\text { elderly) }\end{array}$ \\
\hline & & & & & Elaenty & F: 177.98 & \\
\hline & & & & & 60 to 75 vears & F: 202.6 & \\
\hline Pessin, et al. ${ }^{24}$ & Brazilian & MDVP & /a/ & $N=72$ & ou to 10 years & M: 130.9 & NS \\
\hline T Cosili, Ct al. & & & & 60 to 90 years & 76 to 90 vears & F: 199.4 & TVO \\
\hline & & & & & & M: 133.3 & \\
\hline
\end{tabular}




\begin{tabular}{|c|c|c|c|c|c|c|c|}
\hline Author & $\begin{array}{c}\text { Nationality of the } \\
\text { population }\end{array}$ & Program used & $\begin{array}{c}\text { Stimulus } \\
\text { used }\end{array}$ & $\begin{array}{l}\text { Characteristics of } \\
\text { the population }\end{array}$ & Groups studied & $F_{0}(H z)$ & $p$-value \\
\hline \multirow{20}{*}{ Soltani et al. ${ }^{2}$} & \multirow{20}{*}{ Persian } & \multirow{20}{*}{ PRAAT } & \multirow{20}{*}{ /a/ } & \multirow{20}{*}{$\begin{array}{c}N=400 \\
4 \text { to } 80 \text { years }\end{array}$} & \multirow{2}{*}{4 years } & M: 292.44 & \multirow{20}{*}{$\begin{array}{c}F=\text { lower in the } \\
14 y, 50 y \text { and } \\
60 y \text { groups } \\
(p=0.00)\end{array}$} \\
\hline & & & & & & F: 292.53 & \\
\hline & & & & & \multirow{2}{*}{5 years } & M: 288.33 & \\
\hline & & & & & & F: 289.75 & \\
\hline & & & & & \multirow{2}{*}{7 years } & M: 284.15 & \\
\hline & & & & & & F: 282.40 & \\
\hline & & & & & \multirow{2}{*}{12 years } & M: 219.12 & \\
\hline & & & & & & F: 258.65 & \\
\hline & & & & & \multirow{2}{*}{14 years } & M: 124.32 & \\
\hline & & & & & & F: 217.2 & \\
\hline & & & & & \multirow{2}{*}{$20-22$ years } & M: 118.53 & \\
\hline & & & & & & F: 214.8 & \\
\hline & & & & & \multirow{2}{*}{$30-32$ years } & M: 117.65 & \\
\hline & & & & & & F: 214.2 & \\
\hline & & & & & \multirow{2}{*}{$40-42$ years } & M: 117.81 & \\
\hline & & & & & & F: 213.07 & \\
\hline & & & & & \multirow[b]{2}{*}{$50-52$ years } & M: 114.06 & \\
\hline & & & & & & F: 190.27 & \\
\hline & & & & & \multirow{2}{*}{$60-80$ years } & M: 127.45 & \\
\hline & & & & & & F: 178.96 & \\
\hline $\begin{array}{l}\text { Stathopoulos, } \\
\text { Huber, Sussman }\end{array}$ & American & - & /a/ & $\begin{array}{c}N=192 \\
4 \text { to } 93 \text { years }\end{array}$ & * & * & $\begin{array}{c}p=0.001 \\
(F>M) \\
p=0.001 \\
\text { (age) }\end{array}$ \\
\hline
\end{tabular}

Legend: * not informed by the article; Hz: Hertz; F: Female; M: Male; F0: fundamental frequency; MDVP: Multi-Dimensional Voice Program; MDVPA: Multi-Dimensional Voice Program Advanced; CSL: Computerized Speech Lab; NS: nonsignificant value.

Figure 2. Normality values for $F_{0}$ measurements and $p$-values presented in the literature between the groups studied

The child's voice was investigated by a study involving the voices of children aged four to 12 years ${ }^{18}$. The authors reported that, during childhood, the $F_{0}$ measurement values fall as the person gets older. These changes are explained by natural development, which affects the laryngeal structures as the body grows, e.g., the increase in mass and length of the vocal folds. In small children, values of $275 \mathrm{~Hz}$ for boys and $257 \mathrm{~Hz}$ for girls are expected; by the end of childhood, as they are 11 years old, this measurement is found to be around $220 \mathrm{~Hz}$ and $234 \mathrm{~Hz}$ for boys and girls, respectively ${ }^{18}$, with greater fall during adolescence ${ }^{1-3}$.

During adulthood, based on the consulted literature, it can be observed that $F_{0}$ measurement remains stable $^{12}$, particularly in young adults ${ }^{19}$. Authors found an average $F_{0}$ of $210 \mathrm{~Hz}$ in adult women ${ }^{20}$; in the male population, the values are around $120 \mathrm{~Hz}^{20}$. It is consensual that with aging the measurement of $\mathrm{F}_{0}$ goes through changes, especially in women. However, the beginning of these vocal transformations is not clear. It has been observed that $F_{0}$ remains stable in both genders during adulthood, indicating that changes in this measurement would be expected only in old age $^{12,19}$. Other authors ${ }^{21}$, though, have shown that, in women, decrease in $\mathrm{F}_{0}$ begins even before menopause, at the age of 40 . In addition to acoustic changes, a tendency to differences in auditory perception between the groups has been described, with the presence of greater roughness in middle-aged women, when compared to young women. Thus, the anatomic and physiologic changes that can affect vocal quality and the acoustic parameters of women's voices take place not only in old age, but have their beginning in adulthood, before the hormonal changes occurring in the time of menopause.

According to the investigated literature, the interference of the menstrual cycle in the voice of adult women between 20 and 42 years old was also investigated. The $F_{0}$ is found to be lower in the premenstrual period in relation to the menstrual and postmenstrual periods, because of the increase in mass in the vocal folds resulting from hormonal changes ${ }^{22}$. 
Hence, during adulthood, the $F_{0}$ values are expected to be stable in young adult men and women, though in women such changes may happen prior to the menopause period $^{14,21}$.

With aging, the human voice goes through changes noticeable in $F_{0}$, particularly in women. In general terms, in women, there is a decrease in $F_{0}$ measurements in the elderly population in relation to young women $8,19,23,24$. The decrease in $F_{0}$ found in the literature is justified by the anatomic and hormonal changes taking place in the human larynx $x^{8,12,19}$, as age advances. Other studies, however, have not observed difference in $F_{0}$ values when comparing the voice of young and old women ${ }^{24,25}$, even though the $F_{0}$ is the acoustic parameter that changes most with aging ${ }^{24}$. In relation to the male population, most of the studies found do not point to acoustic changes in the voice of elderly men in relation to the younger ones, $8,19,24,26$. Nevertheless, Dehqan et al. ${ }^{9}$ observed the increase of $F_{0}$ in elderly men when compared to adults, due to the reduction in muscle tissue affecting the male larynx in old age. The main vocal complaints presented in the elderly population are hoarseness, difficulty to sing, and phonatory effort. The most frequent videolaryngoscopic findings are atrophy and arching of vocal folds, especially in older seniors ${ }^{24}$. These anatomic changes in vocal folds of the elderly may justify the changes in $F_{0}$ found in this population. In general, a reduction in $F_{0}$ of up to $40 \mathrm{~Hz}$ has been found when comparing young and old women ${ }^{8,26}$, whereas in the male population, those studies indicating changes between young and old men pointed to an increase of $27 \mathrm{~Hz}$ in the $F_{0}$ of the elderly population.

Two studies made available information concerning transformations in the vocal characteristics throughout life, using the same methodology, reflected by means of the $\mathrm{F}_{0}^{1,2}$, according to the literature consulted. These studies differ from previous ones, which aimed to present information on the $F_{0}$ in specific ages.

One of the studies ${ }^{1}$ brought information regarding voice production, based on information derived from the $F_{0}$, in subjects aged from 4 to 93 years. The authors stated that, throughout life, the vocal production goes through changes, which behave differently in each gender. In men, the $F_{0}$ decreased steadily from 4 to 50 years old, and present an increase after this age. In women, the $F_{0}$ decreased until their 60 years and increased at the age of 80 years, though subtly. The decrease in $F_{0}$ from childhood to adolescence has been explained, according to the authors, by the increase of mass in the vocal folds. During adulthood, hormonal changes resulting from menopause explain the decrease in $F_{0}$ in middle-aged women. In men over 50 years old, there was an increase of $F_{0}$ due to the decrease of mass in the vocal folds.

Another study which investigated changes in the $F_{0}$ throughout life ${ }^{2}$ has shown that this measurement goes through changes from childhood to old age in both genders, with greater changes in males. The authors reported that $F_{0}$ decreased from childhood to adulthood, and the differences between the genders began from the age of 12 , due to differences in this population's craniofacial growth and hormonal development. In adulthood, up until 40 years old, the stabilization of the craniofacial development and hormonal conditions was observed, without changes in the $F_{0}$. In women over 50 years old, there was a decrease of $F_{0}$, justified by the increase of mass in the vocal folds resulting from menopause. In men, there was an increase in $F_{0}$ when they were over 60 years old, justified by the reduction of mass in the vocal folds and changes in the laryngeal muscles and cartilages ${ }^{2}$.

Regarding gender, the consulted studies did not point to differences in the $F_{0}$ between boys and girls in childhood ${ }^{18}$. Such differences begin in puberty, at around the age of 12 years, because of changes in the craniofacial development and hormonal changes taking place in adolescence ${ }^{2}$. After adolescence, men and women present differences in $F_{0}$ in adulthood and old age ${ }^{5,8,9,12,19}$. The $F_{0}$ is influenced by the speaker's gender (and also age), and is changed according to the characteristics of the vocal fold, such as length, mass, tension, vibration and stretching, besides presenting relation with subglottic pressure ${ }^{4}$. Hence, as a consequence of the existing anatomic and physiologic differences in the vocal tract of men and women, such as the difference in size of the larynx and lowering of the tract, for example, the male $F_{0}$ is smaller than the female one. 


\begin{tabular}{|c|c|c|c|c|c|c|c|}
\hline Author & $\begin{array}{l}\text { Nationality of the } \\
\text { population }\end{array}$ & Program used & $\begin{array}{l}\text { Stimulus } \\
\text { used }\end{array}$ & $\begin{array}{l}\text { Characteristics of } \\
\text { the population }\end{array}$ & Groups studied & Jitter (\%) & $p$-value \\
\hline \multirow{7}{*}{$\begin{array}{c}\text { Tavares, Lábio and } \\
\text { Martins }^{18}\end{array}$} & \multirow{7}{*}{ Brazilian } & \multirow{7}{*}{ MDVP } & \multirow{7}{*}{ /a/ } & \multirow{7}{*}{$\begin{array}{c}N=240 \\
4 \text { to } 12 \text { years }\end{array}$} & \multirow{2}{*}{4 to 5 years } & M: 1.71 & \multirow{7}{*}{ NS } \\
\hline & & & & & & F: 1.63 & \\
\hline & & & & & \multirow{2}{*}{6 to 7 years } & M: 1.18 & \\
\hline & & & & & & F: 1.72 & \\
\hline & & & & & \multirow{2}{*}{8 to 9 years } & M: 1.53 & \\
\hline & & & & & & F: 1.62 & \\
\hline & & & & & 10 to 11 years & $\begin{array}{l}\mathrm{M}: 1.70 \\
\mathrm{~F} \cdot 167\end{array}$ & \\
\hline $\begin{array}{l}\text { Finger, Cielo and } \\
\text { Schwarz }{ }^{20}\end{array}$ & Brazilian & PRAAT & /a/ & $\begin{array}{l}N=56 \text { women } \\
18 \text { to } 38 \text { years }\end{array}$ & 18 to 38 years & $\mathrm{F}: 0.42$ & NS \\
\hline Beber and Cielo ${ }^{28}$ & Brazilian & MDVPA & /a/ & $\begin{array}{l}N=25 \text { men } \\
20 \text { to } 40 \text { years }\end{array}$ & 20 to 40 years & M: 1.51 & NS \\
\hline \multirow{5}{*}{$\begin{array}{l}\text { Dehqan, Ansari, } \\
\text { Bakhtiar'2 }\end{array}$} & \multirow{5}{*}{ Iranian } & \multirow{5}{*}{ Dr. Speech } & \multirow{5}{*}{ /a/ } & \multirow{5}{*}{$\begin{array}{c}N=90 \\
20 \text { to } 50 \text { years }\end{array}$} & \multirow{2}{*}{20 to 30 years } & M: 0.24 & \multirow{5}{*}{ NS } \\
\hline & & & & & & F: 0.23 & \\
\hline & & & & & \multirow{2}{*}{30 to 40 years } & M: 0.22 & \\
\hline & & & & & & $F: 0.23$ & \\
\hline & & & & & 40 to 50 years & M: 0.22 & \\
\hline \multirow[b]{2}{*}{ D'Haeseleer et al. ${ }^{21}$} & \multirow[b]{2}{*}{ Belgian } & \multirow[b]{2}{*}{ MDVP } & \multirow[b]{2}{*}{ /a/ } & \multirow{2}{*}{$\begin{array}{c}\mathrm{N}=44 \\
20 \text { to } 28 ; 46 \text { to } 52 \\
\text { years }\end{array}$} & Youth & $\frac{T .0 .22}{F: 0.89}$ & \multirow[b]{2}{*}{ NS } \\
\hline & & & & & Premenopause & F: 0.9 & \\
\hline \multirow{2}{*}{ Demirhan et al. ${ }^{5}$} & Turkich & $C S I$ & la / /i/ lw & $\mathrm{N}=83$ & 18 to 32 verac & M: 0.51 & $p=0.000$ \\
\hline & Iưkish & CSL & $/ \cdots, / \mathrm{l} /, / \mathrm{u} /$ & 18 to 32 years & 18 to 32 years & F: 0.9 & $(F>M)$ \\
\hline & & & & & $\begin{array}{l}\text { Stage: } \\
\text { menstruation } \\
\text { (I) }\end{array}$ & F: 0.68 & \\
\hline Tatar et al. ${ }^{22}$ & Turkish & MDVP & la/ & $\begin{array}{l}N=89 \text { women } \\
20 \text { to } 42 \text { years }\end{array}$ & $\begin{array}{c}\text { Stage: } \\
\text { postmenstruation } \\
\text { (II) }\end{array}$ & F: 0.67 & $\begin{array}{c}p=0.021 \\
(I I I>I I)\end{array}$ \\
\hline & & & & & $\begin{array}{c}\text { Stage: } \\
\text { premenstruation } \\
\text { (III) }\end{array}$ & F: 0.70 & \\
\hline & & & & $\mathrm{N}=41$ & & M: 0.2 & \\
\hline Dahonn & Jrninn & Dre crone & & 70 to 90 years & Youth & F: 0.18 & \\
\hline Dehqan et al. ${ }^{9}$ & Iranian & Dr. Speech & /a/ & $N=40$ & Fldorly & M: 0.31 & (elderly > \\
\hline & & & & 20 to 49 years & Elaenry & F: 0.24 & \\
\hline & & & & $N=159$ & Vouth & M: 0.38 & \\
\hline & Canodian & Sonnoto & & 18 to 28 years; & Youtn & F: 0.37 & \\
\hline Goy et al. & Canadian & Sonneta & /a/ & $N=133$ & Fldorly & M: 0.48 & NS \\
\hline & & & & 63 to 86 years & Elderly & $\mathrm{F}: 0.47$ & \\
\hline & & & & & 60 to 70 years & F: 0.42 & \\
\hline Fonsec 23 & Brazilian & PRAAT & /é/ & Iv -20 & 71 to 80 years & F: 0.78 & NS \\
\hline & & & & over 60 years & +80 years & F: 0.78 & \\
\hline & & & & $\mathrm{N}=60$ women & Youth & F: 0.4 & \\
\hline Menezes et al. ${ }^{25}$ & Brazilian & PRAAT & /a/ & $\begin{array}{l}20 \text { to } 35 \text { years } \\
60 \text { to } 82 \text { years }\end{array}$ & Elderly & F: 0.8 & NS \\
\hline Lortie et al. ${ }^{29}$ & Canadian & PRAAT & $\mid \mathrm{a} /$ & $\begin{array}{c}N=81 \\
20 \text { to } 75 \text { years }\end{array}$ & * & * & $\begin{array}{c}p=0.001 \\
\text { (elderly }> \\
\text { youth) }\end{array}$ \\
\hline & & & & & Youth & M: 0.28 & $p=0.001$ \\
\hline Mezzedimi et al ${ }^{26}$ & Italian & PRAAT & /a/ & $\begin{array}{l}1 N=14 \mathrm{C} \\
20 \text { to } 93 \text { years }\end{array}$ & Fldal & $\begin{array}{l}\text { F: } 0.21 \\
\text { M: } 0.65\end{array}$ & (elderly \\
\hline & & & & & Elderly & F: 0.49 & >youth \\
\hline
\end{tabular}

Legend: * not informed by the article; F: Female; M: Male; MDVP: Multi-Dimensional Voice Program; MDVPA: Multi-Dimensional Voice Program Advanced; CSL: Computerized Speech Lab; NS: nonsignificant value.

Figure 3. Normality values for jitter measurement and p-value presented in the literature between the groups studied 


\section{Jitter}

The short-term perturbation measurements of frequency, jitter, provide information on the cycle-tocycle variation of the vocal folds vibration frequency ${ }^{27}$, and may be related to hoarseness ${ }^{26}$.

The vocal analysis software MDVP (MultiDimensional Voice Program) and PRAAT were the most used in the studies found for this review. The measurements of these programs that are related to this discussion are the local jitter of PRAAT and the jitter (\%) of MDVP, according to nomenclature given by the software $^{19}$, as they are the measurements most often approached in the literature. PRAAT does not present reference values for the comparison between normality and vocal disturbances. The speech-language-hearing therapists that use it in the voice clinic rely on literature data to understand the findings from their assessments. MDVP, on the other hand, and MDVPA (MultiDimensional Voice Program Advanced), which is a variation of the MDVP software, present a normality value for both men and women, without distinction of age group. The normality value for jitter of these two programs is of $1.038 \%$ for men, and $0.633 \%$ for women. In the survey conducted, the jitter measurement in childhood was found in only one study, which reported values for children aged 4 to 11 years from $1.18 \%$ to $1.71 \%$ for boys, and from $1.53 \%$ to $1.72 \%$ for girls ${ }^{18}$. It is observed that this measurement does not change in childhood, and seems to be a stable parameter in this stage of life ${ }^{18}$. Nonetheless, the authors indicated that the greatest variability of this measurement takes place in small children ${ }^{19}$. As for adolescence, there are no reports of studies having investigated this acoustic measurement, according to the survey conducted.

During adulthood, the jitter measurement for women was reported to vary between $0.18 \%$ and $0.9 \%^{5,8-}$ 9,12,20,25,26; two of these studies, by the way, refer to the Brazilian population ${ }^{20,25}$. For men, the values for this measurement varied from $0.2 \%$ to $1.51 \%$,8-9,12,25,26,28. The only Brazilian study ${ }^{28}$ pointed to a value of $1.51 \%$, which is higher than the normality values proposed by the program (Multi-Dimensional Voice Program Advanced - MDVPA) used in the study for adult men. However, discussing normality values between the results is difficult, for the programs used are different and not all of them present normality values, as MDVPA does. Among the studies consulted for jitter measurements, it was observed that aging does not affect them in adult men $^{12}$ and women ${ }^{12,21}$, which points to the stability of this parameter in this stage of life. Particularly in women, jitter measurement was higher in the premenstrual period, in comparison to the menstrual and postmenstrual period, because of hormonal changes in this period ${ }^{22}$. in spite of the slight change in values for jitter, this datum with significant difference points to an increase in perturbation of the acoustic wave in the premenstrual stage.

In old age, some studies indicate that jitter measurement tends to increase as age advances, which may be explained by the stiffness of vocal folds occurring in this stage of life ${ }^{12,26,29}$. In old age, there are physiological changes - such as alterations in glottal closure, asymmetry and irregularity in vibration of vocal folds ${ }^{24}$, which could justify increase in jitter measurements. Despite this, other studies that investigated the elderly's voice indicate that this measurement remains stable in old age and does not reflect the changes resulting from the aging process ${ }^{8,23,25}$, although they comment that, with aging, the vibration of the vocal folds becomes less symmetric and with greater vibratory irregularity. Thus, it was observed that there is no consensus between the studies regarding the behavior of jitter measurements in the elderly population.

Differences between the genders in jitter measurement are not clear. Some authors have not observed differences in this measurement ${ }^{12,18,28}$, while another study, as it investigated the voices of adults aged from 18 to 32 years, reported that jitter is presented more highly among females in relation to males ${ }^{5}$.

\section{Shimmer}

The short-term perturbation measurement of amplitude, shimmer, indicates the cycle-to-cycle variation of the vocal fold in relation to the amplitude of the wave, and is influenced by the age and gender of each person ${ }^{4}$. Increased values of this measurement are related to roughness, hoarseness ${ }^{27}$ and breathiness ${ }^{4,10}$.

The shimmer reference measurements presented in the programs MDVP and MDVPA is of $2.523 \%$ for men, and $1.997 \%$ for women. The shimmer measurements related to this discussion are the local shimmer of the PRAAT software and shimmer (\%) of the MDVP, according to nomenclature given by the software ${ }^{20}$, as they are the most often approached measurements in the literature.

According to the literature, the shimmer measurement does not change in childhood, indicating it to be a stable parameter in this stage of life ${ }^{18}$. Shimmer values for children aged from four to 11 years were 


\begin{tabular}{|c|c|c|c|c|c|c|c|}
\hline Author & $\begin{array}{l}\text { Nationality of the } \\
\text { population }\end{array}$ & Program used & $\begin{array}{l}\text { Stimulus } \\
\text { used }\end{array}$ & $\begin{array}{c}\text { Characteristics of } \\
\text { the population }\end{array}$ & Groups studied & Shimmer (\%) & $p$-value \\
\hline \multirow{6}{*}{$\begin{array}{c}\text { Tavares, Lábio and } \\
\text { Martins }^{18}\end{array}$} & \multirow{6}{*}{ Brazilian } & \multirow{6}{*}{ MDVP } & \multirow{6}{*}{ /a/ } & \multirow{6}{*}{$\begin{array}{c}N=240 \\
4 \text { to } 12 \text { years }\end{array}$} & 4 to 5 years & $\begin{array}{l}\mathrm{M}: 4.36 \\
\mathrm{~F}: 5.05\end{array}$ & \multirow{6}{*}{ NS } \\
\hline & & & & & \multirow{2}{*}{6 to 7 years } & M: 4.01 & \\
\hline & & & & & & F: 5.15 & \\
\hline & & & & & 8 to 9 years & M: 4.24 & \\
\hline & & & & & & $\begin{array}{l}\mathrm{F}: 4.74 \\
\mathrm{M}: 4.01\end{array}$ & \\
\hline & & & & & 10 to 11 years & F: 4.22 & \\
\hline $\begin{array}{l}\text { Finger, Cielo and } \\
\text { Schwarz }\end{array}$ & Brazilian & PRAAT & la/ & $\begin{array}{l}N=56 \text { women } \\
18 \text { to } 38 \text { years }\end{array}$ & 18 to 38 years & F: 2.96 & NS \\
\hline \multirow{4}{*}{$\begin{array}{l}\text { Dehqan, Ansari, } \\
\text { Bakhtiar'2 }\end{array}$} & \multirow{4}{*}{ Iranian } & \multirow{4}{*}{ Dr. Speech } & \multirow{4}{*}{ /a/ } & \multirow{4}{*}{$\begin{array}{c}\mathrm{N}=90 \\
20 \text { to } 50 \text { years }\end{array}$} & 20 to 30 years & \begin{tabular}{|l|} 
M: 1.22 \\
F: 1.23
\end{tabular} & \multirow{4}{*}{ NS } \\
\hline & & & & & 30 to 40 vears & $\mathrm{M}: 1.21$ & \\
\hline & & & & & & $F: 1.22$ & \\
\hline & & & & & 40 to 50 years & $\frac{\text { IVI: } 1.22}{F: 1.20}$ & \\
\hline Beber and Cielo ${ }^{28}$ & Brazilian & MDVPA & la/ & $\begin{array}{c}\mathrm{N}=25 \text { men } \\
20 \text { to } 40 \text { years }\end{array}$ & 20 to 40 years & M: 4.54 & NS \\
\hline \multirow[b]{2}{*}{$D^{\prime}$ Haeseleer et al ${ }^{21}$} & \multirow[b]{2}{*}{ Belgian } & \multirow[b]{2}{*}{ MDVP } & \multirow[b]{2}{*}{ /a/ } & \multirow{2}{*}{$\begin{array}{c}N=44 \\
20 \text { to } 28 ; 46 \text { to } 52 \\
\text { years }\end{array}$} & Youth & $F: 2.38$ & \multirow[b]{2}{*}{ NS } \\
\hline & & & & & Premenopause & F: 1.84 & \\
\hline \multirow{2}{*}{ Demirhan et al..$^{5}$} & \multirow{2}{*}{ Turkish } & \multirow{2}{*}{ CSL } & \multirow{2}{*}{$/ \wedge /, / i /, / u /$} & $N=83$ & \multirow{2}{*}{18 to 32 years } & M: 2.56 & \multirow{2}{*}{$\begin{array}{c}p=0.005 \\
(F>M)\end{array}$} \\
\hline & & & & 18 to 32 years & & $\mathrm{F}: 3.1$ & \\
\hline \multirow{3}{*}{ Tatar et al. ${ }^{22}$} & & & & & $\begin{array}{l}\text { Stage: menstruation } \\
\text { (I) }\end{array}$ & F: 2.25 & \\
\hline & Turkish & MDVP & la/ & $\begin{array}{l}\mathrm{N}=89 \text { women } \\
20 \text { to } 42 \text { years }\end{array}$ & $\begin{array}{c}\text { Stage: } \\
\text { postmenstruation(II) }\end{array}$ & F: 2.11 & $\begin{array}{c}p=0.018 \\
(I I I>\| I)\end{array}$ \\
\hline & & & & & $\begin{array}{c}\text { Stage: } \\
\text { premenstruation (III) }\end{array}$ & F: 2.32 & \\
\hline & & & & $\mathrm{N}=41$ & Youth & $\begin{array}{l}\text { M: } 1.68 \\
F \cdot 165\end{array}$ & $p=0.001$ \\
\hline Dehqan et al. ${ }^{9}$ & Iranian & Dr. Speech & /a/ & $\begin{array}{l}\text { No to gu years } \\
\mathrm{N}=40\end{array}$ & Ful & M: 3.74 & (elderly > \\
\hline & & & & 20 to 49 years & Elderly & F: 2.30 & \\
\hline & & & & $\mathrm{N}=159$ & Youth & M: 2.71 & \\
\hline Goy et al. ${ }^{8}$ & Canadian & Sonneta & $/ \mathrm{a} /$ & 18 to 28 years; & & $F: 2.36$ & $\begin{array}{c}\mathrm{p}=0.001 \\
\mathrm{M}=\text { elderly }\end{array}$ \\
\hline & & & & $\begin{array}{c}N=133 \\
63 \text { to } 86 \text { years }\end{array}$ & Elderly & F: 2.78 & $>$ youth \\
\hline & & & & & 60 to 70 years & F: 2.41 & \\
\hline Fonsec.23 & Brazilian & PRAAT & /é/ & over 60 veare & 71 to 80 years & F: 3.35 & NS \\
\hline & & & & & +80 years & $F: 3.57$ & \\
\hline & & & & $\mathrm{N}=60$ women & Youth & $F: 3.8$ & \\
\hline Menezes et al. ${ }^{25}$ & Brazilian & PRAAT & /a/ & $\begin{array}{l}20 \text { to } 35 \text { years } \\
60 \text { to } 82 \text { years }\end{array}$ & Elderly & $F: 2.8$ & NS \\
\hline Lortie et al. ${ }^{29}$ & Canadian & PRAAT & la/ & $\begin{array}{c}N=81 \\
20 \text { to } 75 \text { years }\end{array}$ & * & * & $\begin{array}{l}p=0.001 \\
\text { (elderly > } \\
\text { youth) }\end{array}$ \\
\hline & & & & $\mathrm{N}=50$ & Elderly & $\mathrm{M}$ and $\mathrm{F}: 5.2$ & $p=0.01$ \\
\hline $\begin{array}{l}\text { Schaeffer, Knudsen } \\
\text { and Small }\end{array}$ & American & MDVP & /a/ & $\begin{array}{l}60 \text { to } 80 \text { years } \\
\quad N=50 \\
20 \text { to } 30 \text { years }\end{array}$ & Youth & $\mathrm{M}$ and $\mathrm{F}: 3.5$ & $\begin{array}{c}(\mathrm{M}>\mathrm{F}) \\
p=0.001 \\
\text { (elderly }> \\
\text { youth) }\end{array}$ \\
\hline & & & & $N=142$ & Youth & $\begin{array}{l}\text { M: } 3.25 \\
\text { F. } 312\end{array}$ & $p=0.001$ \\
\hline Mezzedimi et al. ${ }^{26}$ & Italian & PRAAT & la/ & 20 to 93 years & Elderly & $\begin{array}{l}\text { M: } 6.71 \\
\text { F: } 6.31\end{array}$ & $\begin{array}{c}\text { (elderly }> \\
\text { youth) }\end{array}$ \\
\hline
\end{tabular}

Legend: * not informed by the article; F: Female; M: Male; MDVP: Multi-Dimensional Voice Program; MDVPA: Multi-Dimensional Voice Program Advanced; CSL: Computerized Speech Lab; NS: nonsignificant value.

Figure 4. Normality values for shimmer measurements and p-value presented in the literature between the groups studied 
reported to average $4.1 \%$ and $4.8 \%$ for boys and girls, respectively. As for adolescence, there are no reports of studies having investigated this acoustic measurement, according to the survey conducted.

During adulthood, the studies indicate that shimmer measurement is not influenced by aging in adult men $^{12}$ and women ${ }^{12,21}$. According to the literature, the average is of $2.96 \%$ for females ${ }^{20}$, and $4.5 \%$ for males ${ }^{28}$; however, for men these values are found to be higher than the recommended by the program used (MDVPA).

In the premenstrual period, an increase in shimmer was found in adult women in comparison to the postmenstrual period ${ }^{22}$. In old age, there is an increase in shimmer measurement in the elderly population in relation to the adults ${ }^{9,29,30}$; it is higher in men, a fact explained by the histologic changes that take place in the elderly's vocal fold, such as decrease in the epithelial thickness of the vocal fold and muscle fibers, in addition to the degeneration present in these fibers $^{32,33}$. Such changes in the mucosa and in the vocal muscle could justify an increase in the perturbation measurements in the elderly population. In spite of the increase in the shimmer measurement in the elderly population in relation to adults, when two groups of elderly women were compared, the older one did not present differences in relation to the younger ${ }^{23}$. Another study that investigated young and elderly women did not find change in the shimmer measurement between the groups ${ }^{25}$. Hence, most of the studies indicated an increase in perturbation of amplitude in old age in both men and women, when compared to adults; however, such increase is not expected in comparisons between two different groups of elderly.

Regarding the differences between genders, it was observed that adult women present higher shimmer measurements than adult men, even though other authors had not found distinction in this measure among adults ${ }^{12}$. In old age, higher values of perturbation of amplitude were described in men than in women ${ }^{8,29,30}$. The increase of this measurement in this population is due to the diminished thickness of the vocal folds and to the present arching, caused by presbylarynx, which is more acute in men and affects the stability in vibration of the vocal folds ${ }^{30}$.

\section{Noise Measurements}

The noise measurements take into account the acoustic noise component with the harmonic component present in the sound wave ${ }^{18}$, and they may indicate an aperiodic vibration of the vocal folds ${ }^{34}$. The amount of noise in the vocal signal affects the acoustic signal and seems to reflect the processes involved in the glottal closure ${ }^{1}$. While the NHR (noise-to-harmonic ratio) acoustic measurement relates acoustic noise to the harmonic present in the sound wave ${ }^{18}$, the HNR (harmonic-to-noise ratio) relates the periodic component of the vocal folds signal to the noise present in the signal ${ }^{34}$. In normal voices, increased NHR values or decreased HNR values suggest vocal aging ${ }^{29,30}$. It is important to investigate measurements that pick up noise in the signal, since they can provide important information on the vocal deterioration resulting from aging, as well as on pathological voices (e.g., lesions on the larynx) ${ }^{15,34}$, in which the altered vocal production is presented differently form the expected for normal voices in the various age groups.

The software (MDVP and MDVPA) offers reference values for the NHR parameter, namely: 0.12 for men and 0.11 for women.

The noise measurement was indicated as stable in childhood, as it had not changed in the age group from 4 to 12 years ${ }^{18}$ in both boys and girls. In this study, values were found varying from 0.141 to 0.125 for the boys, and from 0.142 to 0.134 for the girls. There are no reports on this type of measurement in the stage of adolescence, according to the survey conducted.

In adults, a study that investigated young adult and middle-aged women did not find change in the noise measurements in the older group ${ }^{21}$. According to D'Haeseleer ${ }^{21}$, changes in noise measurements would be expected only in old age. Moreover, other authors who investigated different adult age groups observed that the male population presents greater amount of noise in the vocal sign than the female population ${ }^{12}$.

Other authors ${ }^{22}$, when studying different stages of the menstrual cycle in women, indicated that this measurement was found to be higher in the premenstrual period in adult women, when compared with the menstrual and postmenstrual periods, due to the hormonal changes in that period.

Noise measurements during adulthood tend to remain stable in men and women. Nonetheless, men may present a greater amount of noise in the acoustic signal in relation to women. This datum is little discussed in the literature, and there is no consensus in it regarding such result.

The changes involving glottal closure seem to be reflected in noise measurements ${ }^{1}$, and greater amount of noise in the vocal signal in old age reflects vocal deterioration resulting from aging ${ }^{9,29,30}$. An increase 


\begin{tabular}{|c|c|c|c|c|c|c|c|}
\hline Author & $\begin{array}{l}\text { Nationality of the } \\
\text { population }\end{array}$ & Program used & $\begin{array}{l}\text { Stimulus } \\
\text { used }\end{array}$ & $\begin{array}{l}\text { Characteristics of } \\
\text { the population }\end{array}$ & Groups studied & $\begin{array}{c}\text { Noise } \\
\text { measurements } \\
\text { (dB) }\end{array}$ & $p$-value \\
\hline \multirow{5}{*}{$\begin{array}{c}\text { Tavares, Lábio and } \\
\text { Martins }^{18}\end{array}$} & \multirow{5}{*}{ Brazilian } & \multirow{5}{*}{ MDVP } & \multirow{5}{*}{ la/ } & \multirow{5}{*}{$\begin{array}{c}N=240 \\
4 \text { to } 12 \text { years }\end{array}$} & 4 to 5 years & $\begin{array}{l}\text { M: } 0.132 \text { (NHR) } \\
\text { F: } 0.135 \text { (NHR) }\end{array}$ & \multirow{5}{*}{ NS } \\
\hline & & & & & 6 to 7 years & $\begin{array}{l}\text { M: } 0.137 \text { (NHR) } \\
\text { F: } 0.142 \text { (NHR) }\end{array}$ & \\
\hline & & & & & 8 to 9 years & M: 0.141 (NHR) & \\
\hline & & & & & & $\begin{array}{l}\text { F: } 0.135 \text { (NHR) } \\
\text { M: } 0.125 \text { (NHR) }\end{array}$ & \\
\hline & & & & & 10 to 11 years & $\begin{array}{l}\text { F: } 0.134 \text { (NHR) } \\
\text { M: } 0.132 \text { (NHR) }\end{array}$ & \\
\hline $\begin{array}{l}\text { Finger, Cielo and } \\
\text { Schwarz }\end{array}$ & Brazilian & PRAAT & /a/ & $\begin{array}{l}N=56 \text { women } \\
18 \text { to } 38 \text { years }\end{array}$ & 18 to 38 years & F: 0.04 (NHR) & NS \\
\hline Beber and Cielo ${ }^{28}$ & Brazilian & MDVPA & la/ & $\begin{array}{l}\mathrm{N}=25 \text { men } \\
20 \text { to } 40 \text { years }\end{array}$ & 20 to 40 years & M: 0.18 (NHR) & NS \\
\hline \multirow{4}{*}{$\begin{array}{l}\text { Dehqan, Ansari, } \\
\text { Bakhtiar'12 }\end{array}$} & \multirow{4}{*}{ Iranian } & \multirow{4}{*}{ Dr. Speech } & \multirow{4}{*}{ la/ } & \multirow{4}{*}{$\begin{array}{c}N=90 \\
20 \text { to } 50 \text { years }\end{array}$} & 20 to 30 years & $\begin{array}{l}\mathrm{M}: 1.22 \text { (HNR) } \\
\mathrm{F}: 1.23 \text { (HNR) }\end{array}$ & \multirow{4}{*}{$\begin{array}{l}p=0.02 \\
(F>M)\end{array}$} \\
\hline & & & & & 30 to 40 years & M: 1.21 (HNR) & \\
\hline & & & & & & F: 1.22 (HNR) & \\
\hline & & & & & 40 to 50 years & $\begin{array}{l}\text { M: } 1.22 \text { (HNR) } \\
\text { F: } 1.20 \text { (HNR) }\end{array}$ & \\
\hline \multirow[b]{2}{*}{ D'Haeseleer et al. ${ }^{21}$} & \multirow[b]{2}{*}{ Belgian } & \multirow[b]{2}{*}{ MDVP } & \multirow[b]{2}{*}{ la/ } & \multirow{2}{*}{$\begin{array}{c}N=44 \\
20 \text { to } 28 ; 46 \text { to } 52 \\
\text { years }\end{array}$} & Youth & F: 0.12 (NHR) & \multirow[b]{2}{*}{ NS } \\
\hline & & & & & Premenopause & F: 0.12 (NHR) & \\
\hline \multirow{2}{*}{ Demirhan et al..$^{5}$} & \multirow{2}{*}{ Turkish } & \multirow{2}{*}{ CSL } & \multirow{2}{*}{ /^/, /i/, /u/ } & \multirow{2}{*}{$\begin{array}{c}N=83 \\
18 \text { to } 32 \text { years }\end{array}$} & \multirow{2}{*}{18 to 32 years } & M: 0.13 (NHR) & \multirow{2}{*}{ NS } \\
\hline & & & & & & F: 0.13 (NHR) & \\
\hline \multirow{3}{*}{ Tatar et al. ${ }^{22}$} & \multirow{3}{*}{ Turkish } & \multirow{3}{*}{ MDVP } & \multirow{3}{*}{ /a/ } & \multirow{3}{*}{$\begin{array}{l}N=89 \text { women } \\
20 \text { to } 42 \text { years }\end{array}$} & $\begin{array}{c}\text { Stage: } \\
\text { menstruation } \\
\text { (I) }\end{array}$ & F: 0.11 (NHR) & $p=0.03$ \\
\hline & & & & & $\begin{array}{c}\text { Stage: } \\
\text { postmenstruation } \\
\text { (II) }\end{array}$ & F: 0.11 (NHR) & $\begin{array}{l}(|| l \mid l) \\
p=0.00\end{array}$ \\
\hline & & & & & $\begin{array}{c}\text { Stage: } \\
\text { premenstruation } \\
\text { (III) }\end{array}$ & F: 0.13 (NHR) & $(I I I>\| I)$ \\
\hline & & & & $\begin{array}{c}\mathrm{N}=41 \\
70 \text { to } 90 \text { years }\end{array}$ & Youth & $\begin{array}{l}\text { M: } 28 \text { (HNR) } \\
\text { F: } 29.4 \text { (HNR) } \\
\end{array}$ & $p=0.001$ \\
\hline Dehqan et al. ${ }^{9}$ & Iranian & Dr. Speech & la/ & $\mathrm{N}=40$ & Flderly & M: 18.5 (HNR) & (elderly $<$ \\
\hline & & & & 20 to 49 years & Elderly & F: 21.3 (HNR) & \\
\hline Goy et al. ${ }^{8}$ & Canadian & Sonneta & /a/ & $\begin{array}{c}N=159 \\
18 \text { to } 28 \text { years; }\end{array}$ & Youth & $\begin{array}{c}\text { M: } 0.011 \text { (NHR) } \\
\text { F: } 0.007 \text { (NHR) } \\
\text { M: } 0.16 \text { (NHR) }\end{array}$ & NS \\
\hline & & & & $\begin{array}{l}N=133 \\
63 \text { to } 86 \text { years }\end{array}$ & Elderly & F: 0.12 (NHR) & \\
\hline Scarpel and & Prozilion & DP & & $\mathrm{N}=23$ & 60 to 70 years & F: 18.92 (HNR) & \\
\hline Fonseca ${ }^{23}$ & Brazillan & PRAAT & lè/ & over 60 years & $\begin{array}{c}71 \text { to } 80 \text { years } \\
+80 \text { vears }\end{array}$ & $\begin{array}{l}\text { F: } 15.96 \text { (HNR) } \\
\text { F: } 15.30 \text { (HNB) }\end{array}$ & NS \\
\hline & & & & $\mathrm{N}=60$ women & Youth & F: 19.54 (HNR) & \\
\hline Menezes et al. ${ }^{25}$ & Brazilian & PRAAT & $/ \mathrm{a} /$ & $\begin{array}{l}20 \text { to } 35 \text { years } \\
60 \text { to } 82 \text { years }\end{array}$ & Elderly & F: 20.07 (HNR) & NS \\
\hline & & & & & & & $\begin{array}{l}p=0.009 \\
\text { (youth > } \\
\text { middle age }\end{array}$ \\
\hline Lortie et al. ${ }^{29}$ & Canadian & PRAAT & /a/ & $\begin{array}{c}N=81 \\
20 \text { to } 75 \text { years }\end{array}$ & * & HNR & $\begin{array}{l}p=0.001 \\
\text { (youth > } \\
\text { elderly }\end{array}$ \\
\hline & & & & & & & $\begin{array}{c}p=0.008 \\
(F<M)\end{array}$ \\
\hline
\end{tabular}




\begin{tabular}{|c|c|c|c|c|c|c|c|}
\hline Author & $\begin{array}{l}\text { Nationality of the } \\
\text { population }\end{array}$ & Program used & $\begin{array}{l}\text { Stimulus } \\
\text { used }\end{array}$ & $\begin{array}{l}\text { Characteristics of } \\
\text { the population }\end{array}$ & Groups studied & $\begin{array}{c}\text { Noise } \\
\text { measurements } \\
\text { (dB) }\end{array}$ & $p$-value \\
\hline \multirow{2}{*}{$\begin{array}{l}\text { Schaeffer, Knudsen } \\
\text { and Small|30 }\end{array}$} & \multirow{2}{*}{ American } & \multirow{2}{*}{ MDVP } & \multirow{2}{*}{ /a/ } & \multirow{2}{*}{$\begin{array}{c}N=50 \\
60 \text { to } 80 \text { years } \\
N=50 \\
20 \text { to } 30 \text { years }\end{array}$} & Elderly & $\begin{array}{c}M \text { and } F: 0.158 \\
\text { (NHR) }\end{array}$ & \multirow{2}{*}{$\begin{array}{l}\mathrm{p}=0.003 \\
\text { (youth }< \\
\text { elderly) }\end{array}$} \\
\hline & & & & & Youth & $\begin{array}{l}M \text { and F: } 0.133 \\
\text { (NHR) }\end{array}$ & \\
\hline \multirow{3}{*}{ Mezzedimi et al26 } & \multirow{3}{*}{ Italian } & \multirow{3}{*}{ PRAAT } & \multirow{3}{*}{ la/ } & \multirow{3}{*}{$\begin{array}{c}N=142 \\
20 \text { to } 93 \text { years }\end{array}$} & Youth & M: 0.01 (NHR) & \multirow{3}{*}{$\begin{array}{c}\mathrm{p}=0.001 \\
\text { (youth }< \\
\text { elderly) }\end{array}$} \\
\hline & & & & & & $\begin{array}{l}\text { F: } 0.01 \text { (NHR) } \\
\mathrm{M}: 0.05 \text { (NHR) }\end{array}$ & \\
\hline & & & & & Elderly & F: 0.04 (NHR) & \\
\hline \multirow[t]{2}{*}{$\begin{array}{l}\text { Stathopoulos, } \\
\text { Huber, Sussman }\end{array}$} & \multirow[t]{2}{*}{ American } & \multirow[t]{2}{*}{ - } & \multirow[t]{2}{*}{ /a/ } & \multirow[t]{2}{*}{$\begin{array}{c}N=192 \\
4 \text { to } 93 \text { years }\end{array}$} & * & \multirow[t]{2}{*}{ (SNR) } & $\begin{array}{c}\mathrm{p}=0.01 \\
(\mathrm{~F}>\mathrm{M}) \\
\\
\mathrm{p}=0.008 \\
\mathrm{M}=\text { (children } \\
>\text { e elderly) }\end{array}$ \\
\hline & & & & & & & $\begin{array}{c}\mathrm{p}=0.001 \\
\text { (children and } \\
\text { elderly > } \\
\text { adults) }\end{array}$ \\
\hline
\end{tabular}

Legend: * not informed by the article; dB: decibels; M: Male; F: Female; NHR: Noise-to-Harmonic Ratio; HNR: Harmonic-to-Noise Ratio; SNR: Signal-to-Noise Ratio; MDVP: Multi-Dimensional Voice Program; MDVPA: Multi-Dimensional Voice Program Advanced; CSL: Computerized Speech Lab; NS: nonsignificant value.

Figure 5. Normality values for noise measurements and p-value presented in the literature between the groups studied

in the amount of noise in the vocal signal was found in the elderly of both genders, when compared to adults $9,26,29,30$, which points to it as an indicator of vocal aging $^{29}$. The only study that used the MDVP software found the values of 0.158 in the NHR parameter for the elderly. This increase in old age takes place because the noise measurement is related to the changes in perturbation of frequency and amplitude of the wave, besides being related to the subharmonic components. Thus, noise measurements reflect the vocal deterioration caused by aging ${ }^{30}$ and make alterations caused by presbylarynx possible to be objectively measured ${ }^{26}$. In spite of the increase in the amount of noise in the acoustic signal present in old age in comparison to adults, when such measurement was compared in women in three different decades of old age $(60,70$ and 80 years), no differences between the groups were registered $^{23}$. Furthermore, in another study, greater amount of noise was found in women than in men in old age $^{29}$.

In addition to the studies that investigated specific cycles of life, one particular study examined a noise measurement throughout life ${ }^{1}$. A greater amount of noise in acoustic signal was observed in children and in elderly. In children, this is justified by anatomic and physiologic differences which modify the glottal closure; in elderly, by changes in morphology and in the glottal configuration that take place in the presbylarynx, causing the greater amount of noise in the acoustic signal.

Concerning gender, in the child population there are no differences in noise measurements. However, no consensus has been reached as to whether there are differences in the amount of noise in the acoustic signal between men and women in adulthood and old age. While some authors report similarity between the genders in adults and elderly ${ }^{8}$, other studies indicate that in old age there is a greater amount of noise in the vocal signal in the male population, in comparison to the female ${ }^{29,30}$. Furthermore, it has been reported that women over 50 years old present more noise because of the hormonal changes resulting from menopause'.

In summary, based on the survey conducted for this review, it was observed that the $F_{0}$ measurement gradually decreases from childhood to adolescence in both genders, although more abruptly in boys. In adults, this measurement remains stable. With aging, the female voice goes through greater falls in $F_{0}$ in relation to the male, though there is no consensus between the researchers as to when this fall begins, whether before or after the hormonal changes resulting from menopause. The jitter, shimmer and noise 
measurements remain stable throughout childhood and adulthood, and tend to increase with aging, although there is no consensus between authors in relation to the increase in jitter measurement.

During childhood, there is the laryngeal growth and lowering in the vocal tract, the stretching of vocal folds, and the craniofacial development that justify the decrease in $\mathrm{F}_{0}$ in both genders ${ }^{2,4}$. Particularly in adolescence, when the voice is changing, vocal efficiency is diminished because of the increase in size and mass of the larynx and vocal folds, which results from endocrinal control and growth hormones that are produced in this stage of life, causing greater vocal instability ${ }^{35}$. In girls, sexual hormones begin to be produced by the ovaries, and hormonal fluctuations occur throughout the entire reproductive cycle $\mathrm{e}^{36}$; and, in boys, the increase in production of testosterone by the endocrinal system takes place ${ }^{35}$. These changes affect the morphological and functional characteristics of the larynx and, consequently, voice production, as highlighted by Soltani et al. ${ }^{2}$.

During adulthood, the craniofacial, laryngeal and hormonal development stabilize after the adolescence, which reflects in the stability of acoustic parameters ${ }^{1-3}$. For women, in particular, the hormonal fluctuations caused by the process of menopause result in vocal changes ${ }^{36}$.

In old age, the changes occurring in the acoustic measurements are due to anatomophysiologic transformations resulting from the presbylarynx. Morphologically, there are changes in the structure of the vocal folds of the elderly. With aging, the diameter of the vocal muscle fibers diminishes, as compared to the adult ${ }^{32}$, the elastic fibers decrease, and a dense and compact network of collagenous fibers forms in the lamina propria, with fibers in the degenerative process $^{33}$. Besides these, there is atrophy of vocal folds in the elderly, and the epithelial cells are separated due to impairment of the intercellular junction ${ }^{33}$. In some elderly, there is a concentration of fibroblasts in a dense fibrous matrix of the vocal folds, which affects their flexibility and elasticity, thus bringing vocal alterations in the elderly. These morphological transformations occurring in the vocal folds of elderly justify the increase in acoustic parameters of perturbation of frequency and amplitude, as well as those of noise measurements, in addition to changes found in the fundamental frequency.

It has been noticed that, out of the 19 studies analyzed, only investigated acoustic measurements throughout life. These two studies, in particular, enable comparisons to be made of acoustic measurements in the different age groups, as they include speakers of the same language in different cycles of life, using the same software for analysis. Hence, studies are made necessary to investigate the vocal production acoustic characteristics from the child population to old age, using the same methodology, with speakers of the same language, in order to make possible a better understanding of acoustic changes during the different cycles of life. This type of methodology may favor even more its use in the voice clinics. Studies with populations of specific ages are of great importance; however, they do not provide comparable information about the different cycles of life.

The report on differences in results between the various acoustic analyses programs used for vocal assessment makes data comparison more difficult, both in the literature and in clinical practice. Nonetheless, vocal changes taking place throughout life are pointed out to in the researches, regardless of the program used. The reference measurements offered by one of the most used programs in researches found in the literature make no distinction of age group in the values they present. Thus, the professional performing the acoustic analysis of vocal assessment must, in addition to the normality measurements offered by the program, search for the references in the literature, according to the age group of the patient being analyzed.

\section{CONCLUSION}

According to the literature reviewed, from childhood to old age, $F_{0}$ is the acoustic parameter that goes through most changes as one grows up and grows old.

The $F_{0}$ is high during childhood in both genders. With growth and aging, there is a gradual decrease in these values until old age in women, while in men, such decrease takes place until adulthood; regarding old age, there is no consensus whether $F_{0}$ remains stable in the elderly or presents an increase in its values towards the end of the human life.

The jitter, shimmer and noise measurements remain stable during childhood and adulthood in both genders. In old age, there is an increase in shimmer and in the amount of noise in the acoustic signal, with more noise in males. However, the increase in jitter measurement in this stage of life is debatable.

Therefore, it has been observed that the human voice goes through changes throughout life, which are also reflected on the $\mathrm{F}_{0}$, jitter, shimmer and noise 
acoustic measurements. Nevertheless, information on these measurements encompassing a broad age range is scarce, especially with the use of the same methodology. Distinct methodologies are variables that interfere with the analysis of results of the acoustic parameter.

The information presented in this study may be a guidance to future investigations aiming to understand natural changes occurring in the human voice. Furthermore, the summarized information may guide speech-language-hearing therapists in their clinical practice while assessing voice and monitoring therapies.

\section{REFERENCES}

1. Stathopoulos ET, Huber JE, Sussman JE. Changes in acoustic characteristics of the voice across the life span: measures from individuals 4-93years of age. J Speech Lang Hear Res. 2011;54(4):1011-21.

2. Soltani $M$, Ashayeri $H$, Modarresi $Y$, Salavati $M$, Ghomashchi H. Fundamental frequency changes of Persian speakers across the life span. J Voice. 2014;28(3):274-81.

3. Spazzapan EA. Características acústicas da voz de falantes do português brasileiro nos diferentes ciclos da vida [dissertação]. Marília (SP): Universidade Estadual Paulista; 2018

4. Behlau M. Avaliação de voz. In: Behlau M (ed). Voz: o livro do especialista. São Paulo: Revinter; 2001. v.1. p.85-245.

5. Demirhan E, Unsal EM, Yilmaz C, Ertan E. Acoustic voice analysis of young turkish speakers. J Voice. 2016;30(3):378.e21-378.e25.

6. Xue SN, Deliyski D. Effects of aging on selected acoustic voice parameters: preliminary normative data and educational implications. Educational gerontology. 2001;27(2):159-68.

7. Mendes AP, Ferreira LJL, Castro E. Softwares e hardwares de análise acústica da voz e da fala. Distúrb. Comun. 2012;24(3):421-30.

8. Goy H, Fernandes DN, Pichora-Fuller MK, van Lieshout P. Normative voice data for younger and older adults. J Voice. 2013;27(5):545-55.

9. Dehqan A, Scherer RC, Dashti G, AnsariMoghaddam A, Fanaie S. The effects of aging on acoustic parameters of voice. Folia Phoniatr Logop. 2012;64(6):265-70.

10. Ambreen S, Bashir N, Tarar SA, Kausar R. Acoustic analysis of normal voice patterns in pakistani adults. J Voice. 2019;33(1):124.e49-124.e58.
11. Multi-Dimensional Voice Program Model 4305 [manual], Pine Brook, NJ: Kay Elemetrics Corp; 1992.

12. Dehqan A, Ansari H, Bakhtiar M. Objective voice analysis of Iranian speakers with normal voices. J Voice. 2010;24(2):161-7.

13. Christmann MK, Brancalioni AR, Freitas CRD, Vargas DZ, Keske-Soares M, Mezzomo CL et al. Use of the program MDVP in different contexts: a literature review. Rev. CEFAC. 2015;17(4):1341-9.

14. Spazzapan EA, Cardoso VM, Fabron EMG, Berti LC, Brasolotto AG, Marino VMC. Acoustic characteristics of healthy voices of adults: from young to middle age. CoDAS. 2018;30(5):e20170225 DOI: 10.1590/2317-1782/20182017225.

15. Jotz GP, Cervantes O, Abrahão M, Settanni FAP, de Angelis EC. Noise-to-harmonics ratio as an acoustic measure of voice disorders in boys. J Voice. 2002;16(1):28-31.

16. Brockmann M, Drinnan MJ, Storck C, Carding PN. Reliable jitter and shimmer measurements in voice clinics: the relevance of vowel, gender, vocal intensity, and fundamental frequency effects in a typical clinical task. J voice. 2011;25(1):44-53.

17. Howick J, Chalmers I, Glasziou P, Greenhalgh T, Heneghan C, Liberati A et al. "Explanation of the 2011 Oxfor Center for Evidence-Based Medicine (OCEBM) Levels od Evidence (Background Document). Oxford Center for Evidence-Based Medicine. https://www.cebm.net/2016/05/ ocebm-levels-of-evidence/

18. Tavares ELM, Labio RB, Martins RHG. Normative study of vocal acoustic parameters from children from 4 to 12 years of age without vocal symptoms: a pilot study. Braz J Otorhinolaryngol. 2010;76(4):485-90.

19. Zraick RI, Smith-Olinde L, Shotts LL. Adult normative data for the KayPENTAX phonatory aerodynamic system model 6600. J Voice. 2012;26(2):164-76.

20. Finger LS, Cielo CA, Schwarz K. Medidas vocais acústicas de mulheres sem queixas de voz e com laringe normal. Braz $\mathrm{J}$ Otorhinolaryngol. 2009;75(3):432-40.

21. D'haeseleer E, Depypere H, Claeys S, Wuyts FL, Baudonck N, Van Lierde KM. Vocal characteristics of middle-aged premenopausal women. J Voice. 2011;25(3):360-6.

22. Tatar EC, Sahin M, Demiral D, Bayir O, Saylam G, Ozdek A et al. Normative values of voice analysis parameters with respect to menstrual 
cycle in healthy adult Turkish women. $\mathrm{J}$ Voice. 2016;30(3):322-8.

23. Scarpel R, Fonseca MDL. Parâmetros acústicos de vozes de mulheres na pós-menopausa. Rev. Bras. Geriatr. Gerontol. 2014;17(4):741-50.

24. Pessin ABB, Tavares ELM, Gramuglia ACJ, de Carvalho LR, Martins RHG. Voice and ageing: clinical, endoscopic and acoustic investigation. Clin. Otolaryngol. 2017;42(2):330-5.

25. Menezes KSM, Master S, Guzman M, Bortnem C, Ramos LR. Differences in acoustic and perceptual parameters of the voice between elderly and young women at habitual and high intensity. Acta Otorrinolaringologica (English Edition). 2014;65(2):76-84.

26. Mezzedimi C, Di Francesco M, Livi W, Spinosi MC, de Felice C. Objective evaluation of presbyphonia: spectroacoustic study on 142 patients with Praat. J Voice. 2017;31(2):257. e25-257. e32.

27. Maturo S, Hill C, Bunting G, Ballif C, Maurer R, Hartnick C. Establishment of a normative pediatric acoustic database. Arch Otolaryngol Head Neck Surg. 2012;138(10):956-61.

28. Beber BC, Cielo CA. Medidas acústicas de fonte glótica de vozes masculinas normais. Pró-Fono $\mathrm{R}$ Atual Cient. 2010;22(3):299-304.

29. Lortie CL, Thibeault M, Guitton MJ, Tremblay P. Effects of age on the amplitude, frequency and perceived quality of voice. Age. 2015;37(6):117.

30. Schaeffer N, Knudsen M, Small A. Multidimensional voice data on participants with perceptually normal voices from ages 60 to 80 : a preliminary acoustic reference for the elderly population. J Voice. 2015;29(5):631-7.

31. Cerceau JDS, Alves CFT, Gama ACC. Análise acústica da voz de mulheres idosas. Rev. CEFAC. 2009;11(1):142-9.

32. Martins RHG, Pessin ABB, Nassib DJ, Branco A, Rodrigues AS, Matheus SMM. Aging voice and the laryngeal muscle atrophy. The Laryngoscope. 2015;125(11):2518-21.

33. Gonçalves TM, Martins RHG, Pessin ABB. Transmission electron microscopy of the presbylarynx in the process of voice aging. J Voice. 2018;32(1):3-7.

34. Ferrand CT. Harmonics-to-noise ratio: an index of vocal aging. J Voice. 2002;16(4):480-7

35. Fuchs M, Fröehlich M, Hentschel B, Stuermer IW, Kruse E, Knauft D. Predicting mutational change in the speaking voice of boys. $\mathrm{J}$ Voice. 2007;21(2):169-78.

36. Amir $\mathrm{O}$, Wolf $\mathrm{M}$, Amir N. A clinical comparison between two acoustic analysis softwares: MDVP and Praat. Biomedical Signal Processing and Control. 2009;4(3):202-5. 